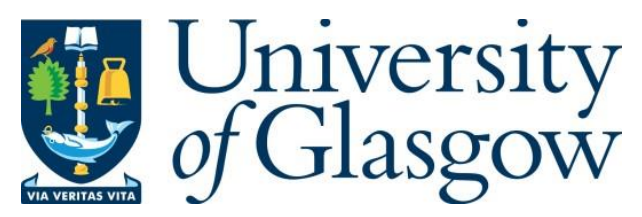

Stephens, M. and Leishman, C. (2017) Housing and poverty: a longitudinal analysis. Housing Studies, 32(8), pp. 1039-1061.

There may be differences between this version and the published version. You are advised to consult the publisher's version if you wish to cite from it.

http://eprints.gla.ac.uk/220451/

Deposited on: 30 January 2017

Enlighten - Research publications by members of the University of Glasgow http://eprints.gla.ac.uk 


\title{
Housing and Poverty: a longitudinal analysis
}

\section{Mark Stephens ${ }^{\mathrm{a}}$ and Chris Leishman ${ }^{\mathrm{b}}$}

a. The Urban Institute, Heriot-Watt University

b. I-SPHERE, Heriot-Watt University

Corresponding author: M.Stephens@hw.ac.uk

Accepted for publication in Housing Studies on 29 January 2017

\begin{abstract}
Cross-sectional research suggests that the British housing system weakens the link between income poverty and housing outcomes, but this reveals little about the longer-term relationships. We examine the relationship between income poverty and housing pathways over an 18 year period to 2008, and develop consensual approaches to poverty estimation, housing deprivation, and the prevalence of under and over-consumption. We find that chronic poverty is most strongly associated with housing pathways founded in social renting, whereas housing pathways founded in owner-occupation are more strongly associated with temporary poverty. Whilst housing deprivation is disproportionately prevalent among those who experienced chronic poverty, the overwhelming majority of people who experienced chronic poverty avoided housing deprivation. This evidence supports of the notion that the housing system, during this period, weakened the link between poverty and housing deprivation. It can be characterised as representing a 'sector regime' with different distributional tendencies from the wider welfare regime.
\end{abstract}




\section{Introduction}

The UK has for some time had one of the highest rates of income poverty among the countries of western and southern Europe. These outcomes have (historically) been linked to the UK's 'liberal' welfare regime that has been distinguished by a 'flexible' labour market and a strong reliance on relatively ungenerous means-tested social assistance benefits. The social insurance system delivers flat-rate benefits that are generally set at or below social assistance benefit rates. In contrast, in addition to more generous social insurance systems, other western European countries have offered higher standards of workplace protection than is the case in the UK. Nonetheless, there have been radical reforms to labour markets and social security in both 'corporatist' (e.g. Germany, see Sandbu, 2016) and 'social democratic' (e.g. Sweden, see Rojas, 2005; Hinde, 2016) countries in response to pressures from globalisation, and there has been an upward movement in poverty rates in these countries. Yet (at 18-20\%) the UK retained one of the highest rates of poverty in the EU-15 throughout the period of this study. In 1995 and 2008 it ranked $12^{\text {th }}$ in the EU-15 (where $15=$ the highest level of poverty) (Eurostat, Table ilc_li02).

There is, however, a body of literature that suggests that the housing system in the UK helps to mitigate the impacts of these high levels of income poverty. This has been labelled the 'saving grace argument' by Tunstall, et al (2013: 31) after a paper by Bradshaw, et al (2008a).

The 'saving grace' hypothesis is founded on features of the housing system. Although in longterm decline, the UK has one of the larger social rented sectors in the European Union. It is targeted on lower-income households, so performs a 'safety net' function, in contrast to a 'wider affordability' function in countries with lower poverty rates such as the Netherlands, Denmark and Sweden (Stephens, et al, 2002; 2003). The 'safety net' in the UK has been reinforced by the legally-enforceable duty of local authorities to find settled accommodation for non-intentionally homeless households in priority need and provides protection some of the most vulnerable households (Fitzpatrick, et al, 2011). Where the social (or non-profit) sector performs a 'wider affordability' function, it reaches further up the income spectrum, but is segmented in such a way as to exclude the poorest and most vulnerable households (Fitzpatrick and Stephens, 2007). Additionally, the UK deploys one of the most extensive (and expensive) housing allowance systems in the world, reflecting the exclusion of an allowance for housing costs in mainstream social security benefits (Stephens, et al, 2010). In terms of the numbers of people who receive it and the proportion of housing costs covered, Housing Benefit performs a vital income maintenance function (Kemp, 2000). In Germany, Sweden, the Netherlands and Denmark the social assistance system performs this function, leaving housing allowances to perform a wider affordability function. Thus assistance with housing costs mimics the operation of the social rented sector (Stephens, et al ,2003; 2010). The UK also has a relatively mature home-ownership sector with the result that most retired households (65\% in 2003/04) and approaching one-third of all households (in 2013/14) enjoy low housing costs by virtue of owning their properties without a mortgage (DWP, 2015). In contrast, in Denmark, the Netherlands and Sweden (but not in Germany) there has been a marked increase in mortgaged home-ownership (Eurostat, Income and Living Conditions). 
These distinctive elements in the UK housing system might be expected to combine and help to weaken the link between income poverty and housing deprivation. Certainly, the cash and in-kind incomes implied by these elements in the housing system do appear to reduce poverty, although this is not unique to the UK (Frick, et al, 2010; Stephens and van Steen, 2011). The 'material' housing outcomes (overcrowding, housing and neighbourhood quality) of poor households may also be better than one might expect, but the evidence is less clear cut (Bradshaw, et al, 2008a; Stephens, et al, 2010). This is important theoretically because it implies a disjuncture (or 'progressive dissonance', as Stephens and van Steen, 2011, termed it) between the UK's 'wider' welfare regime that creates the labour market, tax and security arrangements which gives rise to relatively high levels of income poverty, and its housing regime, which appears to act as a 'corrective.'

This proposition is highly pertinent to the debate within the welfare and housing regime literature as to whether the housing system represents a separate 'sector regime' (Kemeny, 2001). Kemeny (2006) noted that Esping-Andersen (1990) referred to 'pension regimes' and 'labour market regimes' and suggested that housing does indeed represent a distinct 'pillar'. In an attempt to explain inter-sector variation in regime types he hypothesised that different power relationships (between labour and capital) within component pillars could lead to different sector regimes: 'To what extent different sectors are labour-led can vary, regardless of the extent to which the welfare system as a whole is labour-led' (Kemeny, 2006: 9). Kemeny did not, however, consider the distributional implications of this hypothesis, including the proposition under scrutiny here, namely whether the housing system might weaken the link between income poverty and housing deprivation. If the housing system produces different distributional tendencies form the wider welfare regime, then we can characterise it as representing a separate 'sector regime.'

Moreover, one of the key limitations to our understanding of the relationship between housing and poverty is that evidence is based on surveys that record people's experiences at single point in time. Such 'snap shots' tell us little about the evolving relationship between housing and poverty over people's life courses. This article aims to develop an understanding of the long-term relationship between individuals' housing pathways and their experience of poverty, and to establish whether housing represents a separate 'sector regime.'

We employ the 18 waves of the British Household Panel Survey to adopt a longitudinal approach to poverty in order to counter the inadequacy of treating poverty as being a static phenomenon in which the poor are 'contrasted with the non-poor as if they never changed places' (Tomlinson and Walker, 2010: 7). We attempt to capture 'the temporal patterning of poverty and the extent of persistence and scarring' (ibid.) by employing our own typology of temporary, recurrent and chronic poverty. Further, we seek to advance our understanding of the relationship between poverty and housing deprivation by examining its relationship to individuals' housing pathways (after Clapham, 2002), consisting of the combination of tenure sequences that individuals followed with major life events that they experienced. This framework is used to answer our first research question: Are particular housing pathways associated with poverty and its persistence?

We introduce three methodological innovations to enhance the analysis of poverty in housing studies. First, we consider the criticisms of the commonly employed poverty threshold based on 60 per cent of median equivalised incomes as being sufficiently serious to develop an 
alternative to it. This builds on the 'consensual' indicators of deprivation derived from societal norms that have been developed by scholars within the school of distributional studies (after Mack and Lansley, 1985) to develop a predictive consensually-determined poverty line. Because this is expressed in monetary terms, it allows us to consider the impact of housing costs, which cannot be achieved when deprivation is measured directly. Second, we introduce tests for poverty being caused by the unnecessary over-consumption of housing or avoided by its under-consumption.

Third, our consensually-determined indicator of housing deprivation can be compared with the consensually-determined poverty indicator to answer our second research question: Do people who live in poverty also experience housing deprivation? Naturally, we wished to establish not only whether there is a relationship between poverty and housing deprivation, but whether different housing pathways are associated with housing deprivation for people who experience poverty. This led to our third research question: Do people living in poverty have different propensities to experience housing deprivation according to their housing pathway?

The conceptual and operational building blocks for the analysis are established in the next two sections: section 2 deals with poverty and housing deprivation and section 3 with housing pathways. Findings concerning the relationship between housing pathways and poverty are presented in section 4 and those relating to income poverty and housing deprivation in section 5. General conclusions and their implications for theoretical literature are drawn in section 6.

\section{Conceptualising poverty and housing deprivation}

In this section we establish the essential conceptual building blocks to the study. Having described the data source, we examine the options for establishing a conceptually robust poverty threshold; establish a typology to assess the persistence of poverty; examine the treatment of housing costs in the measure of poverty; and suggest a way of identifying over and under-consumption of housing. We then establish an indicator of housing deprivation that is consistent with our concept of poverty.

\section{Poverty and deprivation}

The relativist tradition of Townsend (1979) in the conceptualisation of poverty and deprivation is now widely accepted. It is reflected in the European Commission's characterisation: 'People are said to be living in poverty if their income and resources are so inadequate as to preclude them from having a standard of living considered acceptable in the society in which they live' (Council of the European Union, 2004: 8).

The evidence suggests that deprivation is the consequence of a lack of resources, principally income, but whilst the underlying relationship between income and deprivation is strong, the year-to-year relationship between the two is much weaker (Berthoud, et al, 2011). It seems intuitively plausible that different dimensions of deprivation differ in their sensitivity to income; for example, food insecurity reflects short-term fluctuations in income, whereas indicators of housing deprivation are much less sensitive (Fusco, 2012). 
For this study we required a measure of poverty that met three criteria: to (a) provide a meaningful representation of poverty; (b) be capable of being derived from the available longitudinal data set; and (c) be available in a monetised form, so that housing costs could be taken into account.

We examine the three principal approaches to measuring relative poverty or deprivation against these criteria.

Housing researchers generally adopt a relative poverty threshold based on '60 per cent of equivalised household median income' employed by the European Commission and UK Government. Incomes are measured after tax and social insurance contributions and are adjusted according to the composition of the household, using the OECD's 'modified equivalence scale.' Individuals are identified as living in poverty if they live in a household whose net equivalised income falls below 60 per cent of the national median. In recognition of the significance of housing costs, poverty is often presented before and after actual (as opposed to notional) housing costs are taken into account. After housing cost poverty rates are usually higher than those measured without taking them into account. Yet this approach is now widely criticised in distributional studies literature as being arbitrary (e.g. Bradshaw, et al, 2008b) and providing a threshold that is implausibly high in some countries and implausibly low in some others (Bradshaw and Mayhew, 2010). Whilst this weakness is compounded by the use of an equivalence scale that lacks any scientific basis, its reform would not correct the underlying problem (Bradshaw et al, 2008b). However, in practice almost everyone whose income is below the 60 per cent poverty line is also below the conceptually more robust Minimum Income Standard (described below) (Davis et al, 2014).

An alternative 'consensual' approach has been developed by the Poverty and Social Exclusion (PSE) project (Gordon, et al, 2013). The PSE approach eschews a monetary poverty line, and instead measures 'material deprivation' directly. Approximately decennial surveys identify 'necessities' on the basis of whether half or more of those surveyed believe them to be necessary. If a household lacks three or more items so identified as being necessities (and does not wish to possess them), it is identified as being in multiple deprivation. There is no weighting between different necessities and the approach is open to the objection that the number of necessities that must be lacking is arbitrary. However, there is a strong overlap between those people who are measured as being in multiple deprivation and those people who consider themselves to be poor (Gordon, et al, 2013).

A third approach, developed by the Joseph Rowntree Foundation, addresses these issues by first utilising a consensus approach to identifying a minimum basket of goods and services by consensual means and, second, to identify how much they would cost. The resultant Minimum Income Standard (MIS) 'does not create an acceptable living standard for every individual, but it does suggest a level that is socially unacceptable for any individual to live below' (Bradshaw, et al., 2008b: 4). The MIS does not cover every household type, and 'does not claim to be a poverty threshold' (Padley and Hirsch, 2014: 6). The budget line has been uprated with prices in between rebasing exercises that have taken place every four years since it was established in 2008 (Hirsch, 2013). However, it is not possible to backdate the MIS to the period that our research covered. 
No one of these measures satisfies all three criteria. The PSE measure, whilst arguably a conceptually well-grounded reflection of deprivation, is neither available on a longitudinal basis, and nor is it expressed in monetary terms. The MIS measure is both a conceptually robust reflection of poverty and is expressed in monetary terms. However, it is not available on a sufficient time period for our purposes, having been first established in 2008 . The 60 per cent measure is available both on a longitudinal basis and in a monetary form. Its key weakness is its lack of a conceptual basis, but this is counterbalanced to an extent by the knowledge that most people who are measured as being in poverty under the 60 per cent threshold also have incomes below the MIS.

There are therefore potential benefits to be had in exploring incidence and experience of poverty using an additional, alternative measure of poverty.

We therefore set up an alternative measure of poverty that has similar characteristics to the PSE-style material deprivation, but one that can be constructed within the scope of the BHPS. This dataset includes indicators of desired but unaffordable necessities, albeit a much smaller number than available in PSE. The PSE survey asks people whether they want but cannot afford 46 items, 25 of which are found in a related survey to be considered necessities by 50 per cent or more of people. We followed the PSE convention of defining an individual as being in material deprivation if lacking three of the eight ${ }^{1}$ non-housing necessities that appear in BHPS. (Two further items are housing related (hard to heat home; damp home) and these were excluded from our formula because we seek to establish an after housing cost poverty line. Instead they are used to help to establish whether people are living in housing deprivation.) Having set that indicator, we identified the income below which a majority of people, according to age group and household type, fall into material deprivation. We therefore impute an after housing cost income poverty line associated with material deprivation, and this becomes our poverty threshold. It can be characterised as being a predictive consensuallydetermined poverty line (henceforth 'consensual poverty line').

It meets our three criteria of being a meaningfully grounded representation of poverty or deprivation, is calculable from our longitudinal data set, and comes in a monetised form so it can take into account housing costs. However, because it is novel and there are differences in the populations measured as living in poverty (see Table Al), we employed it beside the 60 per cent measure. The fact that the essential items included in the BHPS did not change throughout the period, also suggests that some of the relativity in the measure is diminished over time, which further justifies employing the two measures.

\section{Persistence of poverty}

Our categorisations of poverty are derived from Tomlinson and Walker (2010), but are modified to reflect the much higher probability of individuals having experienced one measure of poverty or another over such a long period (18 waves). We also prefer the term 'chronic'

\footnotetext{
1 These are: 'can replace furniture,' 'can buy new clothes,' 'eat meat on alternate days,' 'can feed visitors once a month,' 'replace furniture,' 'buy new clothes,' 'eat meat on alternate days,' and 'feed visitors once a month.'
} 
poverty to 'permanent' poverty. Here chronic poverty is defined as two or more spells of poverty lasting for at least three consecutive years during the 18 waves of the BHPS. We define those in recurrent poverty as individuals having experienced at least three spells of poverty lasting one or two years, but never having fallen into chronic poverty during the 18 waves of BHPS. Last, we define those in temporary poverty as people having experienced poverty at least once, but not falling in either of the chronic or recurrent definitions.

\section{Treatment of housing costs}

Housing costs are deeply problematic in the estimation of poverty. They are so significant that they merit separate treatment, which is why it is common to distinguish between poverty before and after housing costs. However, because housing costs vary so much between different parts of the country, within regions, between tenures and within them, it is impossible to allow for a standard allowance for housing when constructing a poverty line. By measuring income after housing costs it is possible to say whether an individual lives in a household with an income that is adequate to avoid non-housing poverty on both 60 per cent our consensual poverty line. But it is not possible to predict accurately what income they would need to pay for adequate housing and still have sufficient income to meet non-housing needs.

We treat housing costs as follows:

Renters: Rent minus Housing Benefit + water rates/ charges + service charges

Owners: Mortgage interest payments, minus ISMI/SMI ${ }^{2}$ + capital repayments (and payments to mortgage-related savings vehicles - e.g. endowments) + structural insurance + ground rent + service charges

These measures differ from those used by the UK Government and EU in two ways. First, Housing Benefit (HB) is treated as a deduction from rent rather than as an addition to income. This is justified because HB is tied to housing consumption and cannot be traded for nonhousing consumption without inducing rent arrears (see Irvine, et al, 2007). Moreover, it brings consistency with social rented housing let at below market rents. However, whichever convention is adopted makes no difference to income after housing costs. Second, we treat mortgage capital repayments as a housing cost, so breaking the convention of treating mortgage capital repayments as savings. However, to reach the happy state of a (more or less) housing cost-free existence, it is necessary to have repaid the mortgage. The variation in home-owners' housing costs across the life course is one of the key effects we sought to capture.

\section{Over and under consumption}

A further complication arises because assessing income after housing costs have been taken tell us only whether the household has sufficient income to meet its non-housing needs. It discounts the possibilities that:

\footnotetext{
2 (Income) Support for Mortgage Interest: a means-tested social security payment that helps homeowners with mortgage interest payments.
} 
- a household lives in non-housing poverty because it has voluntarily consumed more housing than it needs ('overconsumption');

- a household has avoided non-housing poverty only because it has consumed less housing than it needs ('underconsumption').

The conventional measures of after housing cost $(\mathrm{AHC})$ poverty ignore the possibility of over and under consumption.

Having established a minimum housing standard (see 'housing deprivation', below), we can estimate whether a household is over consuming housing voluntarily. ${ }^{3}$

A household may be said to be in poverty through the voluntary over consuming housing if:

(i) The household is not in housing deprivation, and

(ii) Household income is above the before housing cost poverty line, and

(iii) Household income is below the after housing cost poverty line; and

(iv) Household income is less than $20 \%$ below the AHC poverty line, i.e. an even lower income level.

Criterion (i) is a necessary precondition to overconsumption. Criteria (ii) and (iii) are required because poverty must be induced by housing costs. Criterion (iv) is based on the assumption that if a household is taken a long way below the non-housing poverty line by housing costs it is likely to have overconsumed housing out of necessity (i.e. lack of affordable alternative).

A household may be said to be avoiding non-housing poverty by under consuming housing if:

(i) The household is in housing deprivation; and

(ii) Household is not in AHC poverty and

(iii) Household income is no more than $20 \%$ above $\mathrm{AHC}$ poverty line

Criteria (i) and (ii) and both necessary conditions. Criterion (iii) increases the probability that $\mathrm{AHC}$ poverty was avoided by low housing costs. If income were further above the AHC poverty line then it is less likely that the 'savings' in housing costs provide the explanation for the avoidance of poverty.

\section{Housing deprivation}

There has been a growing emphasis on 'housing outcomes' spurred on by the availability of EU-SILC (Statistics on Income and Living Conditions) and the EU's agreed housing indicators (e.g. Borg, 2015; Dewilde, 2015; Stephens et al, 2010; Winters and Heylan, 2014). These indicators include measures of the physical quality of housing, the availability of indoor bathrooms/toilets as well as space standards. They are arbitrary in origin and absolute in

\footnotetext{
${ }^{3}$ The 'spare room subsidy', popularly known as the 'bedroom tax' (introduced after the study period), whereby social renters' Housing Benefit is reduced if they are judged to be underoccupying a dwelling, has demonstrated why it is necessary to establish that over-consumption is voluntary: often households do not have the option to move to smaller accommodation (see also Kutty, 2005).
} 
nature. The comparison between an absolute measure of poverty and a relative measure of income poverty is incongruous, so we needed to identify a relative minimum acceptable standard of housing. In keeping with the consensual approach adopted in above, and we drew on the PSE surveys to identify the key attributes of minimum housing standards.

Adequate space is based on the bedroom standards implied by the PSE survey. More than 70 per cent of respondents (going back to 1983) agree that every child of opposite sex aged 10 or over should have own room. We can impute from this that an adult couple should have their own room, and all other single adults should have their own room. Equally this implies that it is acceptable for children of the same sex to share (we have set the upper age limit on this at 18); and for children of opposite sex to share up to age 10. This differs from the EU indicator, which specifies 12 as the age at which children of the opposite sex should not share (EC, 2009).

To this we have added the requirement for a home to be free of damp (which has commanded at least $90 \%$ support since 1983), and the ability to keep the home adequately warm (which has received at least $95 \%$ support since 1983). Thus we identify someone as living in housing deprivation should their home be overcrowded, and either damp or they are unable to heat it adequately.

\section{Conceptualising and operationalising housing pathways}

There is a long - and living - tradition of research into 'housing careers'. In his widely cited study, Kendig (1984: 271) characterizes a housing career as being 'the sequence of housing states defined in terms of tenure and the quality/price of the dwellings that households occupy while they make parallel careers in family status and the job market'. Whilst the housing careers approach is capable of many different applications, it is frequently founded on the ideal of a linear progression on the 'housing ladder' (Borgersen, 2014), with home-ownership adopted as the 'normalised' destination (Mangnusson Turner and Hedman, 2014).

This approach was subject to an influential critique by Clapham (2002), in which he noted that the careers approach 'concentrated on the price, physical space and quality of the house, which is consumed...' (Clapham, 2002: 64) and related these to certain life course events such as marriage or divorce or the birth of children or certain labour market related changes such as change in employment or unemployment or retirement (ibid.). His critique is founded primarily on an epistemological objection to the positivist underpinnings common in economics. Thus, pathways aim to build on 'careers' to counter some of the frequently-made shortcomings of positivist economics, notably the ubiquitous assumption that actions can always be explained by rational self-interest. In defining a housing pathway Clapham retains the notion of an interaction between housing and life events, 'but also seeks to capture the social meanings and relationships associated with this [housing] consumption...' (2002: 64).

Clapham was not the first scholar to employ housing pathways. Payne and Payne's quantitative study of the housing pathways of 'child-bearing families' in Aberdeen identified housing pathways as representing 'the structure of housing careers' (1977: 129). Although they identify housing pathways purely in tenure terms they are presented as representing choices constrained by structures and resulting in stratification. Housing pathways have attracted scholars employing a range of non-positivist approaches. Clapham himself is 
influenced by social constructionist approaches, whilst Ford, et al (2002) (and updated by Rugg, 2010), adopt a critical realist approach. There are now many studies that employ housing pathways adopting qualitative (e.g. Hochstenback and Boterman, 2015) and mixed (Clapham, et al, 2012) methods. Although young people are frequently the subject of housing pathway studies, scholars have applied the concept to refugees (Murdie, 2007), immigrants (Robinson, et al, 2007), and homelessness (Clapham, 2003).

The underlying challenge is to identify the roles that structural and individual choices play in determining housing outcomes: how much agency is attached to individuals, how constrained are their choices, how strategic their life planning.

There are difficulties in moving from the housing careers to a pathways approach in a large scale statistical exercise. Changes in housing consumption are inevitably captured by moving, tenure change and changes in housing consumption. Indeed, Clapham, et als (2014) study of housing pathways of young people adopts tenure as being a principal characteristic of identified pathways (e.g. 'young professional renters' and 'social renting families'). In this and doubtless other - cases the difference in the use of the terms 'career' and 'pathway' becomes less clear.

This reflects the challenge of large-scale statistical exercises that are required to quantify particular housing pathways. Data sets are inevitably set up around conventional measures of housing tenure, housing size and conditions, household structure, etc. Yet it would be misleading to suggest that these terms are devoid of social meaning, as they arise in qualitative studies that are intended to avoid the imposition of meaningless terms. Moreover, the adoption of indicators of poverty and housing deprivation constructed from societallydetermined attitudes are designed to give them social meaning. This is what pathways are intended to do.

We took the following approach in operationalising housing pathways in order to identify their relationship with poverty and deprivation.

Clapham (2002: 62) identifies '[t]he housing pathway of a household...as...the continually changing set of relationships and interactions, which it experiences over time in its consumption of housing'. Housing pathways seek to capture the relationship between housing consumption and major life events, which may represent 'turning points' (Thomson, et al, 2002). Clapham suggests that although pathways are experienced by the individual, there is no escaping the fact that housing is consumed by households, hence this is the level at which analysis must be undertaken. Here we depart from his approach. Since a housing pathway includes the formation, changes to and dissolution of households it necessary to follow the individual, not the household. This approach is consistent with our treatment of poverty where we follow (and count) the individual, but measure income at the household level.

Individuals may experience a great many life events that might lead to changes in their consumption of housing, particularly when we examine a significant part of their adult lifecourse. If we break down the consumption of housing such that it has a number of dimensions - tenure, quality and quantity - then a substantial number of changes that are of potential interest will be generated ('housing events'). Allowing life events and housing events to interact will reveal housing pathways. The number of such pathways will be large, but they will include some common or dominant pathways, and perhaps many less frequently observed pathways: 
'Households will travel along a particular housing pathway over time. Sometimes the pathway will be a motorway and they will be travelling along with many others. However, there will be junctions at which choices have to be made and part of a journey could be along a small track not often frequented or even involve marking out a new trail.' Clapham (2002: 65)

Moreover, individuals may transfer between pathways, and so it is important that an analysis of housing pathways does not 'over-fit.' For example, what might be described as a set of three pathways might alternatively be defined as two, with recognition that some households transferred from one pathway to another over its life-course. On the other hand, we are seeking to reduce the enormous detail contained within the BHPS to a more manageable level of detail. Therefore a good deal of generalisation is necessary. Here, Clapham's (2002) paper is useful because he sets out four factors that should be retained in any generalisation of individuals' pathways:

(i) Focus on meanings of pathways.

(ii) The characterisation of households as creative agents developing their housing experience through life planning and lifestyle choice.

(iii) The dynamic nature of pathways.

(iv) The importance of social practices and the factors which frame them.

We have discussed the meaning of 'pathway' (factor (i)). Factor (iv) falls into the domain of qualitative research, and is not explored further here. However, factors (ii) and (iii) are central to our approach which considers, as fully as possible, the interplay between life events and housing consumption (including quality and locational choices), whilst taking into account other lifestyle factors such as labour market activity and other types of (non-housing) consumption.

\section{Quantifying housing pathways}

In this section we explain how our pathways were identified. The British Household Panel Survey (BHPS) is the principal longitudinal data set in the UK, initially with more than 10,000 individuals and later receiving sample boosts for Scotland, Northern Ireland and Wales. Like most longitudinal studies, the BHPS samples suffered some attrition, which is known to reduce the generalisability of findings. However, in order to examine people's experiences of housing and poverty over as long a period as possible, we focus only on individuals represented in each of the 18 waves of the BHPS from 1991 to 2008. In addition, whilst the study period obviously falls well short of a whole lifecourse, there is a good spread of ages of participants in wave 1 (Table 1). It may appear tempting to extend the analysis beyond the end of the BHPS in 2008. Unfortunately, its successor, Understanding Society, does not provide consistent measure of housing deprivation. Thus the end of the study in 2008 was informed by the data consistency. However, the onset of the economic crisis in 2008 and the subsequent adoption of austerity policies strengthen the case for choosing 2008 as a suitable end point.

[Table 1 Distribution of BHPS waves 1 and 18 cases by age band] 
Table 1 refers to 4,098 individuals observed in wave 1 and still present in wave 18 . When we consider the tenure sequence followed by these individuals over time, the number of valid cases drops to 2,391 - this is despite a number of steps designed to safely impute missing values. The dominant patterns emerging from the analysis are shown in Table 2

[Table $2 \quad$ Simplified tenure sequences codes and frequencies]

As noted above, the analysis is designed to reveal people's experiences of poverty and their consumption of housing at different stages of their lifecourse. The analysis must consider major demographic, educational and labour market life events in addition to the sequences of tenure, and housing circumstances, of individuals. To permit the analysis to cut through unnecessary detail, and to reveal major patterns, we chose a restricted set of variables designed to capture the most important life events likely to be faced by an individual over the 18 years for which we have data. These included changes to household status (changes to marital status, arrival and departure of dependent children, and household member reaching pensionable age); changes to educational status (when the highest academic qualification changed); and changes to employment status and earnings.

Given the high expected correlations between many paired combinations of these variables, examining the relationships between these 'life event' and tenure sequences could easily generate misleading results. To avoid this, we deployed a well-known data reduction technique - factor analysis - to reduce the majority of the information contained in the life event variables to a smaller set of uncorrelated factors. This yielded a simpler set of four new variables that describe and capture the following phenomena:

- Individuals having volatile patterns of labour market earnings over time;

- Individuals having volatile patterns of housing consumption over time;

- Individuals, through growing older, are experiencing rising incomes and a high likelihood of children growing up and leaving home;

- Individuals changing marital status, acquiring dependent children and consolidating in the labour and housing markets.

The analysis yielded four new variables or factor scores. These can be regarded as being latent variables in the sense that they are not observed directly but represent weighted combinations of the original variables. The important points to note are that they reflect the processes described in the four bullet points above, and that they may be used to identify distinct groups of individuals with different propensities to enter poverty. There are, of course, widely available and sophisticated statistical techniques that permit such propensities to be modelled directly - multilevel modelling and latent growth curve analysis are perhaps the leading examples of these. While these are attractive in the sense that they introduce little or no attrition, there are also disadvantages. In particular, individuals are assumed to share a common trajectory to an outcome (a criticism of 'housing careers'), whereas experience of life events and housing circumstances introduce disruptions to these patterns ('housing pathways'). While factor analysis is arguably more consistent with the concept of housing pathways, it also allows sufficient flexibility to deal with outcomes that are more complex than 
binary, for example whether individuals have experienced poverty or not and, if so, then which of our three defined measures of poverty applies?

Although the factor scores are useful in facilitating the identification of sub-samples, they are not easy to interpret directly. Therefore, having carried out the identification of sub-samples with reference to the factor scores we labelled the sub-samples referring back to the original list of life event variables. This eased interpretation and, in particular, allowed us to consider combinations of housing tenure sequences and life event sub-samples as composite pathways.

Before examining the composite pathways it is worth reiterating that the total number of combinations created by cross-tabulating tenure sequences by life event factor scores is potentially very large. Many of these combinations ('cells') contain very small numbers of cases. To assemble the final combinations of life event/ tenure sequence we adopted the following logical approach:

- We restricted the analysis to combinations of life event variables and tenure that yielded at least 2 per cent of all cases. This reduced the number of sub-samples to 11 , accounting for 1,847 of the original 2,391 cases.

- For a resulting combination of life event/ tenure sequence codes to survive, we required that, (a) the life event code represented at least 15 per cent of cases in the tenure sequence (i.e. the row total); or (b) for life event codes representing less than 15 per cent of cases in the tenure sequence, these only remain in the analysis if at least 50 per cent of cases in the tenure sequence are not accounted for by all surviving life event codes; or (c) for tenure sequences with less than 50 cases, the above criterion is changed to 40 per cent.

Applying this set of criteria reduces the life event codes from eleven to six, but approximately 50 per cent or more of cases on each tenure sequence code are retained. When combined with the tenure sequences, this results in 16 composite pathways. These are examined in the following section.

\section{Experiences of poverty between different pathways}

In the following analysis the 16 pathways are grouped according to the tenure sequence, but are examined alongside life events in Tables 3-6. In interpreting these tables, it is important to recognise that the co-incidence of any form of poverty with housing pathway does not imply causality between them.

Overall, on both measures of poverty adopted, just under 40 per cent of individuals experienced some form of poverty (after housing costs) over the 18 years under consideration (see row labelled 'Total' in Table 3). However, for the overwhelming majority (around 70\%) this was a temporary phenomenon. Nonetheless, one in ten people experienced chronic poverty. This represented about one-quarter of all poverty. Relatively few people experienced recurrent poverty, representing three or more incidents of poverty lasting less than three years. 
Housing costs increased the proportion of individuals living in poverty by around two percentage points. However, we refined the relationship between housing costs and poverty by identifying the prevalence of poverty caused by voluntary over consumption of housing and those who avoid it by its underconsumption. We found only one case of such overconsumption and 113 of underconsumption in the last wave of the BHPS. These phenomena would therefore appear to be rare.

\section{Settled owner occupation pathways}

Almost two-thirds of individuals in the sample were home-owners throughout the entire 18 year period, so can be characterised as being on a 'settled' pathway. Table 3 shows that, on both measures of poverty, although people on settled owner occupation pathways experienced a similar chance of experiencing some form of poverty over the period, compared to the sample as a whole, the form that poverty took was more likely to be temporary and less likely to be chronic. The dominance of settled home-owners in the sample means that their experiences have a large impact on the total figures, the importance of which becomes clear when we examine people on settled social renting pathways.

There is little variation in the level or composition of poverty in the interaction between tenure sequence and life events, suggesting that tenure is the dominant characteristic of these pathways. The life events with which settled home-owners are most strongly associated are having children and rising incomes, rising incomes and ageing. This would be consistent with a benign experience of home-ownership whereby mortgage costs are high when incomes are rising, and falling incomes associated with retirement may be offset by lower levels of mortgage debt later on in the lifecourse.

Nonetheless, between three and seven per cent of individuals on the pathways represented in rows 1-3 did experience chronic poverty. A more detailed analysis of these individuals found that the chance of experiencing chronic (or recurrent) poverty rises with changes in marital status. However, neither causality nor sequence between these life events and the experience of poverty can be inferred from this observation alone.

[Table $3 \quad$ Settled owner occupation pathways]

Around five per cent of people in the sample were home-owners throughout the period, but shifted between outright and mortgaged ownership (row 4). People in this tenure sequence also experienced more volatile incomes, and this group is associated with a higher level of chronic poverty compared to other settled home owners on the consensual poverty line, but a higher level of temporary poverty on the 60 per cent measure.

\section{Transition to home-ownership from private and social renting}

Around five per cent of the sample completed the transition from private renting to home ownership during the 18 year period (Table 4). The individuals in this group who also experienced fluctuations in their labour market position, combined with changes in marital 
status and having children experienced slightly higher than average chances of experiencing poverty. However, this group experienced relatively low levels of chronic poverty, and this contrasts with individuals experiencing the same tenure sequence, but with no significant life event patterns.

[Table 4 The transition to home-ownership]

Around three per cent of the sample made the transition from social renting to homeownership. This group is likely to include those people who exercised the right to buy. The distinctive life events within this sequence are children leaving home and retirement plus falling incomes. These are suggestive of the later stages of working age, which might help to explain the above average overall poverty rates, particularly among those individuals who retired at some point during the 18 year period. Those with children leaving home and retirement plus falling incomes experienced notably high levels of recurrent poverty, though not consistently between poverty measures.

Of those individuals who made the transition from social renting to home-ownership, but who also experienced chronic or recurrent poverty, we found low incidences of dependent children joining the household, low incidences of rising qualifications and high incidences of children leaving (on the $60 \%$ measure) and ageing with falling incomes (according to the consensual poverty line).

\section{Settled social renting pathways, and transition to social renting}

Around eight per cent of individuals in the sample were social renters throughout the 18 years under consideration (rows one and two of Table 5). This group can be broken down broadly into two sub-groups: those who experienced rising incomes and those who retired at some point during the period.

They are distinguished by very high chances of experiencing poverty. They are more than 1.5 and sometimes almost twice as likely to have experienced some form of poverty during the period compared to the total sample. Moreover most of those who experienced poverty experienced chronic poverty. The figures in Table 5 imply that between one-third and one half of people who were social renters throughout the period experienced chronic poverty.

[Table 5 Social Rented pathways]

Only one per cent of the sample made the transition from private renting to social renting for the rest of the period (row 3 of Table 5). This group is not associated with any significant life events. Like settled social renters individuals in this group experience very high levels of poverty, and chronic poverty in particular (especially on the 60 per cent measure).

\section{Fluctuating pathways}


About three per cent of the sample fluctuated between private renting and mortgaged ownership. As tenure sequence it is associated with a variety of life events. Three of the four life event groups that make up this tenure sequence contain either fluctuating incomes and/ or labour market change. The consistent feature of two of these housing pathways is very high levels of temporary poverty.

The fourth life event group that makes up his tenure sequence is associated with changing marital status and ageing (row 4 of Table 6). This pathway has a markedly different poverty pattern from the others in this tenure sequence. This group experiences levels of temporary poverty that are close to the average, but above average levels of chronic poverty.

[Table 6 Fluctuating pathways]

A small proportion of the sample (2.3\%) moved between social renting and mortgaged ownership and back during the period (row 5 of Table 6). The tenure sequence is overwhelmingly associated with people with fluctuating incomes, which seems to give rise to relatively high levels of poverty, although the poverty pattern is inconsistent between the two measures of poverty.

\section{Private renting}

There were insufficient people who remained private renters throughout the period to conduct an analysis in the same way as for other tenure sequences.

\section{Discussion}

The evidence from this analysis shows that, in answer to our first research question, there are very distinct associations between particular housing pathways and poverty. Settled homeowner pathways are associated with above average levels of temporary poverty and low levels of chronic poverty, whereas settled social rented pathways are associated with above average levels of total poverty and in particular of chronic poverty. In both cases it is the tenure sequence that dominates the housing pathway, which suggests that tenure may 'sort' people according to income. These tendencies are found on both measures of poverty.

\section{Poverty, deprivation and housing consumption}

Our second research question is: what is the association between (form of) poverty and housing deprivation? Housing deprivation is identified when someone lives in a damp or hard to heat house which is also overcrowded at some point during the 18 year study period. The question is best addressed by two subsidiary questions, which we address in turn. 
Table 7 indicates that that all forms of poverty together exert either a modest or almost nonexistent effect on the chances of experiencing housing deprivation. Around 45 per cent of people who experienced housing deprivation experienced poverty on the 60 per cent measure and around 40 per cent on the consensual measure. The first of these is about 20 per cent higher ( $45 \%$ vs $38 \%$ ) than the general poverty rate, whereas the second is almost identical. However, there is a much stronger association between the experience of housing deprivation and chronic poverty. The rate of chronic poverty is 2.4-2.6 times higher among people who experienced housing deprivation than the general rate of chronic poverty rate. $(60 \%: 26 / 10$; Consensual 22/9) These findings are consistent with previous work that suggests that deprivation is associated with low incomes over a sustained period. However, it is equally notable that most (55 or $61 \%$ ) of people who experienced housing deprivation over the 18 year period had no encounter with poverty whatsoever.

[Table 8 Overlap between poverty status and experience of housing deprivation]

Table 8 indicates that people who experienced poverty over the 18 year period were at least twice as likely as people who did not to have experienced housing deprivation at some point during the same period. On the 60 per cent measure of poverty those who experienced chronic poverty were most likely to also have experienced housing deprivation, but this is not the case on the consensual measure. An important implication is that, regardless of the form of poverty experienced, at least 84.5 per cent of people who experienced poverty at any point over the 18 year period avoided housing deprivation.

\section{Discussion}

This allows us to answer our second research question. Whilst people who experienced housing deprivation are much more likely to have experienced chronic poverty compared to the population as a whole, the vast majority of people who experienced any form of poverty, including chronic poverty, avoided housing deprivation. For almost everyone the link between poverty, including chronic poverty, and housing deprivation is broken.

[Table 9 The experience of chronic poverty and housing deprivation by housing pathway]

Our third research question is: do people living in poverty have different propensities to experience housing deprivation according to their housing pathway? We further examined the incidence of people in each housing pathway who experienced chronic poverty to also have experienced housing deprivation (Table 9). The general finding that the vast majority of people experienced chronic poverty avoided housing deprivation holds across all four groups of pathways. It is notable that across both measures of poverty, there is no consistent difference 
between the incidence of people on settled home-ownership pathways and people on social rented pathways who experienced chronic poverty to experience housing deprivation. Very few people on fluctuating pathways who experienced chronic poverty also experienced housing deprivation. People who experienced chronic poverty within the group of pathways representing transitions to home-ownership experienced notably higher levels of housing deprivation. Even then at least eight in ten of them avoided housing deprivation.

There were some individual pathways within these groups where the incidence of people who experienced chronic poverty also experiencing housing deprivation was much higher than average. Ageing home-owners and ageing people who made the transition to homeownership from private renting are examples of these. Indeed (according to the consensual poverty line) the majority of people on the social renting to home-ownership pathway when combined with falling incomes experienced housing deprivation. This is the only one of the 16 pathways where this is the case.

\section{Discussion}

This allows us to answer the third research question. On the four sets of housing pathways at least 85 per cent of people who experienced chronic poverty avoided housing deprivation. Crucially this finding holds both for people who experienced settled home-ownership and those who experienced settled social renting pathways.

\section{Conclusion}

This article aimed to develop an understanding of the long-term relationship between individuals' housing pathways and their experience of poverty. By 'housing pathways', we mean the combination of tenure sequence, housing consumption and a wider set of life events including change in household composition, demographic change and labour market outcomes. During the 18-year period over which individuals were tracked, the housing tenure element of the housing pathways dominated over the life event element. There is a very clear relationship between housing pathways and poverty: it is as if housing tenure sorts people according to their incomes. Without a counterfactual, we cannot know to what extent the elements of the housing system outlined in the introduction (social rented housing targeted on low-income groups, legal protection for homeless households, Housing Benefit, and high levels of outright ownership) keep people out of poverty, or reduce its depth or duration. However, even the deep subsidies implied by below market rents in the social rented sector and the extensive take-up of Housing Benefit in the social rented sector are insufficient to prevent high levels of chronic poverty among people on settled social rented pathways. Nevertheless, although there remains a relationship between chronic poverty and housing deprivation, the vast majority of people who experienced chronic poverty escaped housing deprivation, regardless of whether their housing pathway was dominated by owner occupation or social renting.

These findings provide a new dimension to our understanding of the relationship between housing and the 'wider welfare regime.' The study by Stephens and van Steen (2011) showed that 'housing income' helped to reduce income poverty by assisting disproportionately people on low monetary incomes. It therefore enjoyed a 'dissonant' relationship with the distributional 
pattern produced by the labour market and tax and social security system. This study suggests in terms of housing deprivation (a material, rather than monetised housing outcome), the housing regime offers protection to even the most chronically poor households over a long period. Given the way in which the housing system 'mimics' the social security system through the 'safety net', it seems that the institutions created by the housing regime achieve this result by being consistent with those of the 'wider welfare regime'. In other words, they are suited to the high-income poverty context in which they operate. Where the distributional consequences of the housing regime counter those of the wider welfare regime, the housing regime can be characterised as being a separate 'sector regime.'

Nonetheless, three limitations to the study should be noted. First, our chosen methodological approach is by no means the only one that might have been used. Choice of method almost always introduces limitations. The principal one associated with our choice relates to significant attrition of our sample. Alternatives such as multi-level modelling or latent growth curve analysis might avoid this, but suffer from different limitations discussed above. Second, there was the lack of evidence on experience of people whose housing pathways included substantial spells renting privately. This arose from the small scale of the sector in the earlier parts of the study. Third, a consequence of focusing on the people who were present in all 18 waves means that the analysis applied to people whose circumstances were relatively stable. It may be that there were more people with coincident experiences of poverty and housing deprivation, but they were lost through attrition.

Nonetheless, by introducing a substantial longitudinal element, the findings strengthen the cross-sectional evidence that suggests that the British housing system up to 2008 was something of a 'saving grace' of the welfare state. Subsequent developments in housing policy, particularly in England (see Stephens and Stephenson, 2016), suggest that this conclusion is likely to require revision.

\section{Appendix}

Table Al Overlap analysis between poverty measures

\section{References}

Berthoud, R., Bryan, M. (2011) Income deprivation and Poverty: A Longitudinal Analysis, Journal of Social Policy, 40(1), pp. 135-156

Borg, I (2015) Housing Deprivation in Europe: On the role of Rental Tenure Types, Housing, Theory and Society, 32(1): 73-93

Borgersen, T (2014) Housing Careers, House Price Dispersion and the Housing Market Multiplier, Housing, Theory and Society, 31(1): 91-118

Bradshaw, J. and Mayhew, E. (2010) Understanding extreme poverty in the European Union, European Journal of Homelessness, 4, 171-186

Bradshaw, J, Chzhen, Y. and Stephens, M. (2008a) Housing: the saving grace in the British welfare state? in Fitzpatrick, S and Stephens, M (eds) The Future of Social Housing, London: Shelter: 7-25

Bradshaw, J, Middleton, S, Davis, A, Oldfield, N, Smith, N, Cudsworth, L and Williams, J (2008b) A minimum income standard for Britain: what people think, York: Joseph Rowntree Foundation 
Clapham, D (2002) Housing Pathways: A Post Modern Analytical Framework, Housing, Theory \& Society, 19, 2: 57-68

Clapham, D (2003) Pathways approaches to homelessness research, Journal of Community \& Applied Social Psychology, 13(2): 1099-1298

Clapham, D, Mackie, P, Orford, S, Thomas, I and Buckley, K (2014) The housing pathways of young people in the UK, Environment and Planning A, 46: 2016-2031

Council of the European Union (2004) Joint report by the Commission and the Council on social inclusion, Brussels: Council of the European Union

DWP (2013) Households below average income, London; DWP

DWP (2015) Family Resources Survey, UK 2013/14, London: DWP

Dewilde, C (2015) Housing Regimes and Housing Outcomes in Europe, HOWCOME Working Paper No 10, Tilburg University

European Commission (2009) Set of Indicators Approved on 30 June 2009. Definitions and data tables, Brussels: European Commission, unpublished

Eurostat (2015) People at Risk of Poverty and Social Exclusion, http://ec.europa.eu/eurostat/statisticsexplained/index.php/People at risk of poverty or social exclusion (accessed 14 October 2015)

Eurostat (n.d.) Income and Living Conditions http://ec.europa.eu/eurostat/web/income-and-livingconditions/overview

Fitzpatrick, S and Stephens, M (2007) An International Review of Homelessness and Social Housing Policy, London: Department for Communities and Local Government

Fitzpatrick, S., Johnsen, S. and White, M. (2011) Multiple exclusion homelessness in the UK: Key patterns and intersections', Social Policy and Society, 10(4): 501-512

Ford, J, Rugg, J and Burrows, R (2002) Conceptualising the contemporary role of housing in the transition to adult life in England, Urban Studies 39(13): 2455-2467

Frick, J. R., Grabka, M. M., Smeeding, T. M. \& Tsakloglou, P. (2010) Distributional effects of imputed rents in five European countries, Journal of Housing Economics, 19(3): 167-179.

Fusco, A (2012) The relationship between income and housing deprivation in Luxembourg: a longitudinal analysis, CPS/INSTEAD Working Paper No 2012-10, February

Gouldon, C and D'Arcy, C (2014) A Definition of Poverty, York: Joseph Rowntree Foundation

Gordon, D, Mack, J, Lansley, S, Main, G, Nandy, S, Patsios, N, Pomati M (2013) The Impoverishment of the UK, Bristol: PSE

Hochstenbach, $\mathrm{C}$ and Boterman, WR (2015) Navigating the field of housing: housing pathways of young people in Amsterdam, Journal of Housing and the Built Environment, 30(X): 257-274

Hinde, D (2016) A Utopia Like and Other: Inside the Swedish Model, Edinburgh: Luath Press 
Kemeny, J (2001) Comparative housing and welfare: Theorising the relationship, Journal of Housing and the Built Environment, 16:1, 53-70 (DOI:10.1023/A:1011526416064)

Kemeny, J (2006) Corporatism and Housing Regimes, Housing, Theory and Society, 23:1, 1-18

Kemp, P. (2000) The role and design of income-related housing allowances, International Social Security Review, 52(3), pp. 43-53

Irvine, A., Kemp P.A. and Nice, K (2007) Direct Payment of Housing Benefit: What do Claimants Think?, York: Joseph Rowntree Foundation

Kendig, HL (1984) Housing Careers, Life Cycle and Residential Mobility: Implications for the Housing Market, Urban Studies, 21(3): 271-283

Kutty, N (2005) A new measure of housing affordability: estimates and analytical results, Housing Policy Debate, 16(1): 113-142

Mack, J and Lansley, S (1985) Poor Britain, London, George Allen \& Unwin

MagnussonTurner, L and Hedman, L (2014) Linking Integration and Housing Career: A Longitudinal Analysis of Immigrant Groups in Sweden, Housing Studies, 29(2): 270-290

Murdie, R (2008) Pathways to Housing: The Experiences of Sponsored Refugees and Refugee Claimants in Accessing Permanent Housing in Toronto, International Journal of Migration \& Integration, 9(1): 81-101

Padley, M and Hirsch, D (2014) Households below a Minimum Income Standard 2008/09-2011/12, York: Joseph Rowntree Foundation

Payne, J and Payne, G (1977) Housing Pathways and Stratification: a study of life chances in the housing market, Journal of Social Policy, 6(2): 129-156

Robinson, D, Reeve, K and Casey, R (2007) The housing pathways of new immigrants, York: Joseph Rowntree Foundation

Rojas, M (2005) Sweden after the Swedish Model: From Tutorial State to Enabling State, Stockholm: Timbro

Rugg, J. (2010) Young People and Housing: A New Policy Agenda. York: Joseph Rowntree Foundation

Sandbu, M (2016) Germany: an economic giant on a feet of clay, Review of Fratzscher, M (2016) Verteilungskampf: Warum Desutschland immer ungleicher wird (Distribution Battle: why Germany is becoming ever more unequal), Carl Hanser, in Financial Times, 26 July

Stephens, M., Burns, N. and MacKay, L. (2002) Social Market or Safety Net? British Social Rented Housing in a European Context, Bristol: Policy Press

Stephens, M, Burns, N and McKay, N (2003) The limits of housing reform: British social rented housing in a European context, Urban Studies, 40:4, 767-789

Stephens, M Fitzpatrick, S Elsinga, M van Steen, G \& Chzhen, Y 2010, Study on Housing Exclusion: Welfare Policies, Labour Market and Housing Provision, Brussels: European Commission 
Stephens, M, \& van Steen, G 2011, 'Housing Poverty' and Income Poverty in England and The Netherlands, Housing Studies, 26, 7/8: 1035-1057

Stephens, M and Stephenson, A (2016) Housing Policy in the Austerity Age and Beyond in: Fenger, M., Hudson, J. and Needham, C. (eds.) (2016) Social Policy Review 28. Analysis and Debate in Social Policy, Bristol: Policy Press: 63-85

Thomson, R Bell, R Holland, J Henderson, S McGrellis, S and Sharpe S (2002) Critical Moments: Choice, Chance and Opportunity in Young People's Narratives of Transition, Sociology, 36: 335-354

Tomlinson, M. and Walker, R. (2010) Recurrent poverty: the impact of family and labour market changes, York: Joseph Rowntree Foundation.

Townsend, P. (1979) Poverty in the United Kingdom, London: Allen Lane and Penguin

Tunstall, R, Bevan, M, Bradshaw, J, Croucher, K, Duffy, S, Hunter, C, Jones, A, Rugg, J, Wallace, A and Wilcox, S (2013) The Links between Housing and Poverty: an Evidence Review, York: Joseph Rowntree Foundation

Winters, S and Heylan, K (2014) How housing outcomes vary between Belgium regions, Journal of Housing and the Built Environment, 29:541-556 
Table 1 Distribution of BHPS waves 1 and 18 cases by age band

\begin{tabular}{|l|l|l|l|l|}
\hline Age band & $\begin{array}{l}\text { Wave 1 } \\
\text { Frequency }\end{array}$ & Percent & $\begin{array}{l}\text { Wave 18 } \\
\text { Frequency }\end{array}$ & Percent \\
\hline $16 / 17$ & 124 & 3.03 & & \\
\hline $18 / 19$ & 112 & 2.73 & & \\
\hline $20-29$ & 847 & 20.67 & & \\
\hline $30-39$ & 983 & 23.99 & 445 & 10.86 \\
\hline $40-49$ & 918 & 22.40 & 971 & 23.69 \\
\hline $50-59$ & 610 & 14.89 & 919 & 22.43 \\
\hline $60-69$ & 398 & 9.71 & 862 & 21.03 \\
\hline $70+$ & 105 & 2.56 & 901 & 21.99 \\
\hline
\end{tabular}

\section{Table 2 Simplified tenure sequences codes and frequencies}

\begin{tabular}{|l|l|}
\hline Tenure sequence & Percent \\
\hline Home ownership & 64.7 \\
\hline In and out of private renting and mortgaged owning & 3.2 \\
\hline In and out of social renting and mortgaged owning & 2.3 \\
\hline Owning sometimes with or without mortgage & 5.3 \\
\hline Private renting then owning & 4.7 \\
\hline Private then social renting & 1.0 \\
\hline Social renting & 8.2 \\
\hline Social renting then owning & 2.8 \\
\hline Residual & 7.8 \\
\hline
\end{tabular}


Table 3 Settled owner occupation pathways

\begin{tabular}{|c|c|c|c|c|c|c|c|c|c|}
\hline \multirow[b]{2}{*}{ 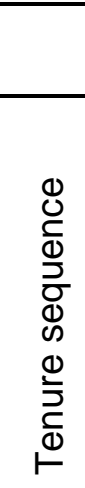 } & \multirow[b]{2}{*}{$\begin{array}{l}\text { Life event } \\
\text { differences } \\
\text { WITHIN } \\
\\
\text { tenure } \\
\text { sequence }\end{array}$} & \multicolumn{4}{|c|}{\begin{tabular}{|l|} 
Below $60 \%$ of median \\
income $(\mathrm{AHC})$ \\
\end{tabular}} & \multicolumn{4}{|c|}{$\begin{array}{l}\text { Consensual } \\
\text { Poverty line }(\mathrm{AHC})\end{array}$} \\
\hline & & 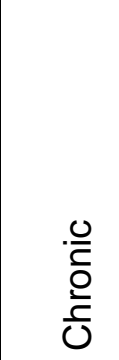 & 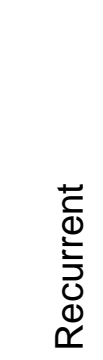 & 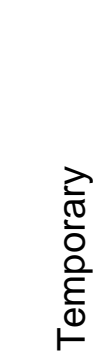 & $\begin{array}{l}\bar{\pi} \\
\text { 0ँ }\end{array}$ & $\begin{array}{l}\frac{0}{\frac{0}{c}} \\
\frac{0}{\frac{1}{U}}\end{array}$ & 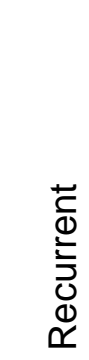 & 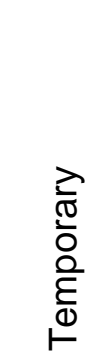 & तٓ \\
\hline $\mathrm{HO}$ & $\begin{array}{l}\text { Children } \\
\text { leaving } \\
\text { rising incomes }\end{array}$ & 7.1 & 0.6 & 29.4 & 37.1 & 5.2 & 0 & 28.7 & 33.9 \\
\hline $\mathrm{HO}$ & $\begin{array}{l}\text { Rising } \\
\text { incomes }\end{array}$ & 7.2 & 0 & 29.2 & 36.4 & 5.8 & 0.6 & 28.5 & 34.9 \\
\hline $\mathrm{HO}$ & Ageing & 7.1 & 0.5 & 28.6 & 36.2 & 3.1 & 0 & 29.6 & 32.7 \\
\hline $\begin{array}{l}\mathrm{OO} \\
\Leftrightarrow \\
\mathrm{MO}\end{array}$ & $\begin{array}{l}\text { Fluctuating } \\
\text { incomes }\end{array}$ & 1.9 & 0 & 33.8 & 35.7 & 11.3 & 0 & 27.1 & 38.4 \\
\hline Tot & & 10.2 & 0.7 & 26.7 & 37.6 & 9.4 & 1.5 & 27.7 & 38.6 \\
\hline
\end{tabular}

Note: (a) Figures are percentages of row totals, i.e poverty rates for each pathway. Total = all individuals in all pathways 
Table 4 The transition to home-ownership

\begin{tabular}{|c|c|c|c|c|c|c|c|c|c|}
\hline \multirow[b]{2}{*}{ 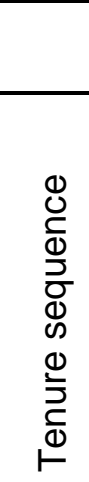 } & \multirow[b]{2}{*}{$\begin{array}{l}\text { Life event } \\
\text { differences } \\
\text { WITHIN } \\
\\
\text { tenure } \\
\text { sequence }\end{array}$} & \multicolumn{4}{|c|}{$\begin{array}{l}\text { Below } 60 \% \text { of median } \\
\text { income }(\mathrm{AHC})\end{array}$} & \multicolumn{4}{|c|}{$\begin{array}{l}\text { Consensual } \\
\text { Poverty line }(\mathrm{AHC})\end{array}$} \\
\hline & & $\begin{array}{l}\frac{0}{\frac{0}{T}} \\
\frac{0}{\frac{0}{U}}\end{array}$ & 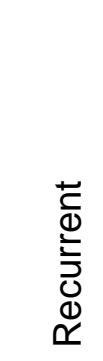 & 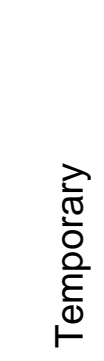 & 要 & $\begin{array}{l}\frac{0}{\bar{L}} \\
\frac{0}{\frac{0}{U}} \\
U\end{array}$ & 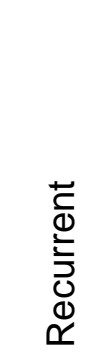 & $\begin{array}{l}\frac{2}{\pi} \\
\frac{0}{0} \\
\frac{0}{0} \\
\frac{0}{1}\end{array}$ & $\begin{array}{l}\text { त्व } \\
\stackrel{0}{0}\end{array}$ \\
\hline $\begin{array}{l}\mathrm{PR} \\
\overrightarrow{\mathrm{HO}}\end{array}$ & $\begin{array}{ll}\Delta & \text { labour } \\
\text { market } & +\Delta \\
\text { marital } & \\
\text { children } & \\
\end{array}$ & 0 & 0 & 38.9 & 38.9 & 5.6 & 5.6 & 31.2 & 42.4 \\
\hline $\begin{array}{l}\mathrm{PR} \\
\overrightarrow{\mathrm{HO}}\end{array}$ & $\begin{array}{ll}* * * & \text { No } \\
\text { significant life } \\
\text { event patterns }\end{array}$ & 17.4 & 4.3 & 24.4 & 46.1 & 13 & 4.3 & 26.3 & 43.6 \\
\hline $\begin{array}{l}\mathrm{SR} \\
\overrightarrow{\mathrm{HO}}\end{array}$ & $\begin{array}{l}\text { Children } \\
\text { leaving }\end{array}$ & 6.7 & 13.3 & 28.1 & 48.1 & 20 & 0 & 25.2 & 45.2 \\
\hline $\begin{array}{l}\mathrm{SR} \\
\overrightarrow{\mathrm{HO}}\end{array}$ & $\begin{array}{ll}\text { Ageing } & + \\
\text { falling } & \\
\text { incomes } & \\
\end{array}$ & 25 & 0 & 31.3 & 56.3 & 12.5 & 12.5 & 29.2 & 54.2 \\
\hline Tot & & 10.2 & 0.7 & 26.7 & 37.6 & 9.4 & 1.5 & 27.7 & 38.6 \\
\hline
\end{tabular}

Note: (a) Figures are percentages of row totals, i.e poverty rates for each pathway. Total = all individuals in all pathways 
Table 5 Social Rented pathways

\begin{tabular}{|c|c|c|c|c|c|c|c|c|c|}
\hline \multirow[b]{2}{*}{ 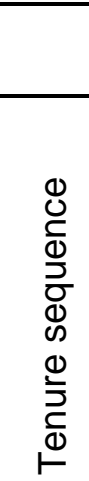 } & \multirow[b]{2}{*}{$\begin{array}{l}\text { Life event } \\
\text { differences } \\
\text { WITHIN }\end{array}$} & \multicolumn{4}{|c|}{$\begin{array}{l}\text { Below } 60 \% \text { of median } \\
\text { income }(\mathrm{AHC})\end{array}$} & \multicolumn{4}{|c|}{$\begin{array}{l}\text { Consensual } \\
\text { Poverty line }(\mathrm{AHC})\end{array}$} \\
\hline & & 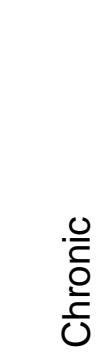 & 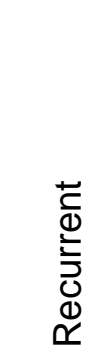 & 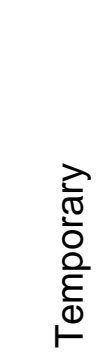 & $\begin{array}{l}\bar{\pi} \\
\stackrel{0}{0} \\
\vdash\end{array}$ & $\begin{array}{l}\frac{.0}{\frac{1}{2}} \\
\frac{0}{\frac{0}{0}}\end{array}$ & 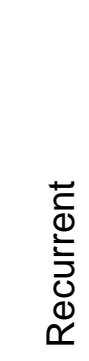 & 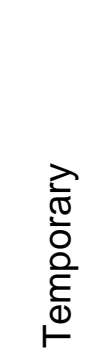 & 要 \\
\hline SR & $\begin{array}{l}\text { Rising } \\
\text { incomes }\end{array}$ & 50 & 2.3 & 21.3 & 73.6 & 38.6 & 6.8 & 20.1 & 65.5 \\
\hline SR & Ageing & 34.6 & 3.8 & 31.2 & 69.6 & 46.2 & 3.8 & 18.4 & 68.4 \\
\hline $\begin{array}{l}\mathrm{PR} \\
\overrightarrow{\mathrm{SR}} \\
\end{array}$ & $\begin{array}{ll}* \star * & \text { No } \\
\text { significant life } \\
\text { event patterns }\end{array}$ & 60 & 0 & 17.2 & 77.2 & 30 & 10 & 20 & 60 \\
\hline Tot & & 10.2 & 0.7 & 26.7 & 37.6 & 9.4 & 1.5 & 27.7 & 38.6 \\
\hline
\end{tabular}

Note: (a) Figures are percentages of row totals, i.e poverty rates for each pathway. Total = all individuals in all pathways 
Table 6 Fluctuating pathways

\begin{tabular}{|c|c|c|c|c|c|c|c|c|c|}
\hline \multirow[b]{2}{*}{ 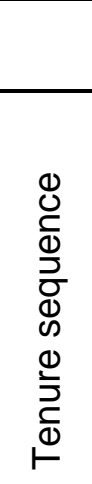 } & \multirow[b]{2}{*}{$\begin{array}{l}\text { Life event } \\
\text { differences } \\
\text { WITHIN } \\
\\
\text { tenure } \\
\text { sequence }\end{array}$} & \multicolumn{4}{|c|}{$\begin{array}{l}\text { Below } 60 \% \text { of median } \\
\text { income }(\mathrm{AHC})\end{array}$} & \multicolumn{4}{|c|}{$\begin{array}{l}\text { Consensual } \\
\text { Poverty line (AHC) }\end{array}$} \\
\hline & & $\begin{array}{l}\frac{0}{\frac{0}{D}} \\
\frac{0}{\frac{0}{U}}\end{array}$ & 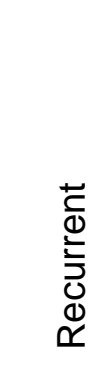 & 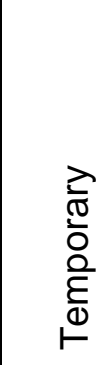 & क्ञ̃ & 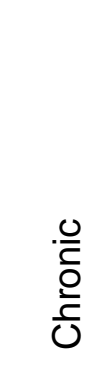 & 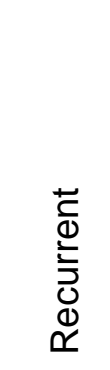 & 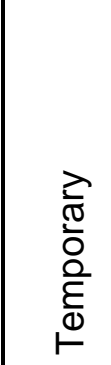 & 要 \\
\hline $\begin{array}{l}\mathrm{PR} \\
\Leftrightarrow \\
\mathrm{MO}\end{array}$ & $\begin{array}{l}\text { Fluctuating } \\
\text { incomes }+\Delta \\
\text { labour market } \\
+\Delta \text { marital } \\
\text { status } \quad+ \\
\text { children }\end{array}$ & 0 & 0 & 40.7 & 40.7 & 8.3 & 0 & 32.9 & 41.2 \\
\hline $\begin{array}{l}\mathrm{PR} \\
\Leftrightarrow \\
\mathrm{MO}\end{array}$ & $\begin{array}{l}\text { Fluctuating } \\
\text { incomes }+\Delta \\
\text { marital status }\end{array}$ & 10 & 0 & 41.7 & 51.7 & 20 & 30 & 16.1 & 66.1 \\
\hline $\begin{array}{l}\mathrm{PR} \\
\Leftrightarrow \\
\mathrm{MO}\end{array}$ & $\begin{array}{lr}\Delta & \text { labour } \\
\text { market r } & + \\
\text { children } & \\
\text { leaving } & \\
\end{array}$ & 0 & 0 & 34.9 & 34.9 & 0 & 0 & 34.9 & 34.9 \\
\hline $\begin{array}{l}\mathrm{PR} \\
\Leftrightarrow \\
\mathrm{MO}\end{array}$ & $\begin{array}{lr}\Delta & \text { marital } \\
\text { status } & + \\
\text { ageing } & \\
\end{array}$ & 14.3 & 0 & 27.8 & 42.1 & 14.3 & 0 & 27.8 & 42.1 \\
\hline $\begin{array}{l}\mathrm{SR} \\
\Leftrightarrow \\
\mathrm{MO}\end{array}$ & $\begin{array}{l}\text { Fluctuating } \\
\text { incomes }\end{array}$ & 0 & 0 & 48.1 & 48.1 & 27.8 & 5.6 & 21.6 & 55 \\
\hline Tot & & 10.2 & 0.7 & 26.7 & 37.6 & 9.4 & 1.5 & 27.7 & 38.6 \\
\hline
\end{tabular}

Note: (a) Figures are percentages of row totals, i.e poverty rates for each pathway. Total = all individuals in all pathways 
Table 7 Percentage of people who experienced housing deprivation who experienced poverty

\begin{tabular}{|l|c|c|c|c|}
\hline & In chronic poverty & $\begin{array}{l}\text { In recurrent } \\
\text { poverty }\end{array}$ & $\begin{array}{l}\text { In temporary } \\
\text { poverty }\end{array}$ & $\begin{array}{l}\text { Any form of } \\
\text { poverty }\end{array}$ \\
\hline $\begin{array}{l}\text { Below 60\% of } \\
\text { median }\end{array}$ & 26.3 & 2.8 & 15.4 & 44.6 \\
\hline $\begin{array}{l}\text { Consensual } \\
\text { poverty line }\end{array}$ & 22.1 & 3.9 & 13.3 & 39.3 \\
\hline
\end{tabular}

Note: figures are percentages of people living with housing deprivation who are also in poverty according to each measure.

Table 8 Overlap between poverty status and experience of housing deprivation

\begin{tabular}{|l|c|c|}
\hline Poverty status & $\begin{array}{l}\text { Percentage who experienced } \\
\text { housing deprivation } \\
\text { poverty line) }\end{array}$ & $\begin{array}{l}\text { Percentage who } \\
\text { experienced housing } \\
\text { deprivation } \\
\text { (consensual poverty } \\
\text { line) }\end{array}$ \\
\hline Temporary poverty & 10.0 & 12.7 \\
\hline Recurrent Poverty & 11.9 & 15.5 \\
\hline Chronic poverty & 14.2 & 5.5 \\
\hline No experience of poverty & 5.2 & 11.0 \\
\hline
\end{tabular}

Note: figures as percentages of people who experienced (for example) temporary poverty who also experienced housing deprivation 
Table 9 The experience of chronic poverty and housing deprivation by housing pathway

Table 9a Settled home-ownership pathways

\begin{tabular}{|c|c|c|c|}
\hline \multicolumn{2}{|l|}{ Pathway } & & \\
\hline $\begin{array}{l}\text { Tenure } \\
\text { sequence }\end{array}$ & $\begin{array}{l}\text { Life event } \\
\text { differences } \\
\text { within tenure } \\
\text { sequence }\end{array}$ & $\begin{array}{l}\text { Chronic } \\
\text { poverty } \\
(60 \%) \text { and } \\
\text { housing } \\
\text { deprivation }\end{array}$ & $\begin{array}{l}\text { Chronic } \\
\text { Poverty } \\
\text { (consensual) } \\
\text { and housing } \\
\text { deprivation }\end{array}$ \\
\hline $\mathrm{HO}$ & $\begin{array}{l}\text { Children } \\
\text { leaving } \\
\text { rising } \\
\text { incomes }\end{array}$ & 0.9 & 0.4 \\
\hline $\mathrm{HO}$ & $\begin{array}{l}\text { Rising } \\
\text { incomes }\end{array}$ & 1.9 & 1.7 \\
\hline $\mathrm{HO}$ & Ageing & 21.2 & 12.5 \\
\hline $\mathrm{OO} \Leftrightarrow \mathrm{MO}$ & $\begin{array}{l}\text { Fluctuating } \\
\text { incomes }\end{array}$ & 0.0 & 0.0 \\
\hline $\begin{array}{l}\text { All settled } \\
\text { home- } \\
\text { ownership }\end{array}$ & & 3.5 & 5.4 \\
\hline
\end{tabular}

Table 9c Social renting pathways

\begin{tabular}{|c|c|c|c|}
\hline \multicolumn{2}{|l|}{ Pathway } & & \\
\hline $\begin{array}{l}\text { Tenure } \\
\text { sequence }\end{array}$ & $\begin{array}{l}\text { Life event } \\
\text { differences } \\
\text { within tenure } \\
\text { sequence }\end{array}$ & $\begin{array}{l}\text { Chronic } \\
\text { poverty } \\
(60 \%) \text { and } \\
\text { housing } \\
\text { deprivation }\end{array}$ & $\begin{array}{l}\text { Chronic } \\
\text { Poverty } \\
\text { (consensual) } \\
\text { and housing } \\
\text { deprivation }\end{array}$ \\
\hline SR & $\begin{array}{l}\text { Rising } \\
\text { incomes }\end{array}$ & 0.0 & 0.0 \\
\hline SR & Ageing & 9.8 & 7.3 \\
\hline $\mathrm{PR} \rightarrow \mathrm{SR}$ & $\begin{array}{l}* * * \quad \text { No } \\
\text { significant life } \\
\text { event } \\
\text { patterns }\end{array}$ & 14.8 & 7.4 \\
\hline $\begin{array}{l}\text { All social } \\
\text { renting }\end{array}$ & & 6.6 & 5.6 \\
\hline
\end{tabular}


Table 9b Transition to home-ownership pathways

\begin{tabular}{|c|c|c|c|}
\hline \multicolumn{2}{|l|}{ Pathway } & \multirow[b]{2}{*}{$\begin{array}{l}\text { Chronic } \\
\text { poverty } \\
(60 \%) \text { and } \\
\text { housing } \\
\text { deprivation }\end{array}$} & \multirow[b]{2}{*}{$\begin{array}{l}\text { Chronic } \\
\text { Poverty } \\
\text { (consensual) } \\
\text { and housing } \\
\text { deprivation }\end{array}$} \\
\hline $\begin{array}{l}\text { Tenure } \\
\text { sequence }\end{array}$ & $\begin{array}{l}\text { Life event } \\
\text { differences } \\
\text { within tenure } \\
\text { sequence }\end{array}$ & & \\
\hline $\mathrm{PR} \rightarrow \mathrm{HO}$ & $\begin{array}{lr}\Delta & \text { labour } \\
\text { market } & +\Delta \\
\text { marital } & + \\
\text { children } & \end{array}$ & 11.1 & 0.0 \\
\hline $\mathrm{PR} \rightarrow \mathrm{HO}$ & $\begin{array}{ll}* \star \star & \text { No } \\
\text { significant life } \\
\text { event } \\
\text { patterns }\end{array}$ & 0.0 & 0.0 \\
\hline $\mathrm{SR} \rightarrow \mathrm{HO}$ & $\begin{array}{l}\text { Children } \\
\text { leaving }\end{array}$ & 0.0 & 36.1 \\
\hline $\mathrm{SR} \rightarrow \mathrm{HO}$ & $\begin{array}{l}\text { Ageing } \quad+ \\
\text { falling } \\
\text { incomes }\end{array}$ & 31.5 & 61.1 \\
\hline $\begin{array}{l}\text { All } \\
\text { transition to } \\
\text { home- } \\
\text { ownership }\end{array}$ & & 13.2 & 19.0 \\
\hline
\end{tabular}

Table 9d Fluctuating pathways

\begin{tabular}{|c|c|c|c|}
\hline \multicolumn{2}{|l|}{ Pathway } & \multirow[b]{2}{*}{$\begin{array}{l}\text { Chronic } \\
\text { poverty } \\
(60 \%) \text { and } \\
\text { housing } \\
\text { deprivation }\end{array}$} & \multirow[b]{2}{*}{$\begin{array}{l}\text { Chronic } \\
\text { Poverty } \\
\text { (consensual) } \\
\text { and housing } \\
\text { deprivation }\end{array}$} \\
\hline $\begin{array}{l}\text { Tenure } \\
\text { sequence }\end{array}$ & $\begin{array}{l}\text { Life event } \\
\text { differences } \\
\text { within tenure } \\
\text { sequence }\end{array}$ & & \\
\hline $\mathrm{PR} \Leftrightarrow \mathrm{MO}$ & $\begin{array}{l}\text { Fluctuating } \\
\text { incomes }+\Delta \\
\text { labour market } \\
+\Delta \quad \text { marital } \\
\text { status } \quad+ \\
\text { children }\end{array}$ & 0.0 & 0.0 \\
\hline $\mathrm{PR} \Leftrightarrow \mathrm{MO}$ & $\begin{array}{l}\text { Fluctuating } \\
\text { incomes }+\Delta \\
\text { marital status }\end{array}$ & 2.8 & 0.0 \\
\hline $\mathrm{PR} \Leftrightarrow \mathrm{MO}$ & $\begin{array}{l}\Delta \quad \text { labour } \\
\text { market } \\
\text { children } \\
\text { leaving }\end{array}$ & 0.0 & 0.0 \\
\hline $\mathrm{PR} \Leftrightarrow \mathrm{MO}$ & $\begin{array}{lr}\Delta & \text { marital } \\
\text { status } & + \\
\text { ageing } & \end{array}$ & 0.0 & 0.0 \\
\hline $\mathrm{SR} \Leftrightarrow \mathrm{MO}$ & $\begin{array}{l}\text { Fluctuating } \\
\text { incomes }\end{array}$ & 4.4 & 0.0 \\
\hline $\begin{array}{l}\text { All } \\
\text { fluctuating } \\
\text { pathways }\end{array}$ & & 3.1 & 0.0 \\
\hline
\end{tabular}




\section{Appendix}

Table Al Overlap analysis between poverty measures

\begin{tabular}{|l|c|}
\hline & $\begin{array}{c}\text { Percentage of } \\
\text { cases still in } \\
\text { this category } \\
\text { under } \\
\text { consensual } \\
\text { measure }\end{array}$ \\
\hline People in temporary poverty & 54.1 \\
\hline People in recurrent AHC poverty & 3.0 \\
\hline People in chronic AHC poverty & 42.8 \\
\hline People with no experience of AHC poverty & 94.5 \\
\hline
\end{tabular}

\begin{tabular}{|l|c|}
\hline & $\begin{array}{c}\text { Percentage of } \\
\text { cases still in } \\
\text { this category } \\
\text { under } 60 \% \\
\text { measure (after } \\
\text { housing costs) }\end{array}$ \\
\hline Consensual measure & 79.3 \\
\hline People in temporary poverty & 2.8 \\
\hline People in recurrent poverty & 39.5 \\
\hline People in chronic poverty & 91.8 \\
\hline $\begin{array}{l}\text { People with no experience of imputed consensual measure of } \\
\text { poverty }\end{array}$ & \begin{tabular}{c} 
\\
\hline
\end{tabular} \\
\hline
\end{tabular}

